\title{
Air temperature variations and gradients along the coast and fjords of western Spitsbergen
}

\author{
Herdis M. Gjelten, ${ }^{1}$ Øyvind Nordli, ${ }^{2}$ Ketil Isaksen, ${ }^{2}$ Eirik J. Førland, ${ }^{1}$ Pavel N. Sviashchennikov, ${ }^{3,4}$ \\ Przemyslaw Wyszynski, ${ }^{5}$ Uliana V. Prokhorova, ${ }^{4}$ Rajmund Przybylak, ${ }^{5}$ Boris V. Ivanov ${ }^{4,6}$ \& \\ Alexandra V. Urazgildeeva ${ }^{4}$ \\ 1 Observation and Climate Department, Norwegian Meteorological Institute, PO Box 43 Blindern, NO-0313 Oslo, Norway \\ ${ }^{2}$ Research and Development Department, Norwegian Meteorological Institute, PO Box 43 Blindern, NO-0313 Oslo, Norway \\ ${ }^{3}$ Climatology and Environmental Monitoring Department, St. Petersburg State University, Universitetskaya nab. 7-9, RU-199034, St. Petersburg, Russia \\ ${ }^{4}$ Arctic and Antarctic Research Institute, RU-199397 Bering str. 38, St. Petersburg, Russia \\ ${ }^{5}$ Department of Meteorology and Climatology, Nicolaus Copernicus University, Lwowska 1, PL-87-100 Torun, Poland \\ ${ }^{6}$ Oceanology Department, Institute of Earth Sciences, St. Petersburg State University, Universitetskaya nab. 7-9, RU-199034, St. Petersburg, Russia
}

\section{Keywords}

Svalbard; Arctic; trends; development; warming; temperature changes.

\section{Correspondence}

Herdis M. Gjelten, Observation and Climate

Department, Norwegian Meteorological

Institute, PO Box 43 Blindern, NO-0313

Oslo, Norway. E-mail: herdismg@met.no

\begin{abstract}
Daily temperature measurements from six meteorological stations along the coast and fjords of western Spitsbergen have been digitized and quality controlled in a Norwegian, Russian and Polish collaboration. Complete daily data series have been reconstructed back to 1948 for all of the stations. One of the station's monthly temperature series has previously been extended back to 1898 and is included in this study. The long-term series show large temperature variability on western Spitsbergen with colder periods in the 1910s and 1960s and warmer periods in the 1930s, 1950s and in the 21 st century. The most recent years are the warmest ones in the instrumental records. There is a positive and statistically significant trend in the annual times series for all of the stations; however, the strongest warming is seen in winter and spring. For the period 1979-2015, the linear trends range from 1.0 to $1.3^{\circ} \mathrm{C} /$ decade for the annual series and from 2.0 to $2.3^{\circ} \mathrm{C} /$ decade in winter. Threshold statistics demonstrate a decrease in the number of cold days per year and an increase in the number of warm days. A decreasing inter-annual variability is observed. In winter, spring and autumn, the stations in the northernmost areas of west Spitsbergen and in the innermost parts of Isfjorden are the coldest ones. In summer, however, the southernmost station is the coldest one.
\end{abstract}

To access the supplementary material for this article, please see the supplementary files under Article Tools, online.
The increase in annual average temperature between 1980 and 2009 was twice as high over the Arctic as it was over the rest of the world (AMAP 2012; Fig. la), and it is likely that there has been an anthropogenic contribution to this substantial warming (Bindoff et al. 2013). This warming is due to a combination of a general background warming, anomalies in the atmospheric circulation and a reduced sea-ice extent and higher sea-surface temperatures (Serreze et al. 2011) in addition to strong low-level stability and cloud conditions (Graversen et al. 2014; Pithan \& Mauritsen 2014). However, there are large variations in the temperature development in the Arctic, both on annual, decadal and longer time scales. Periods with enhanced temperatures occurred, for example, in the 1920s and 1930s-“early 20th century warming" (e.g., Brönnimann 2009) - and in the 1950s, followed by colder periods. A further enhanced warming of the Arctic is projected for the rest of the century. Depending on the forcing scenario, global temperature projections show a mean Arctic warming between 2.2 and 2.4 times the global average warming for 2081-2100 compared to 1986-2005 (Collins et al. 2013). 
The Svalbard Archipelago $\left(74^{\circ}-81^{\circ} \mathrm{N}, 10^{\circ}-35^{\circ} \mathrm{E}\right.$; Fig. 1) is one of the northernmost land areas in the Arctic Ocean. The climate is governed by negative radiation balance, large-scale atmospheric circulation and sea-surface temperature and sea-ice extent in the adjacent sea areas (Førland et al. 1997; Svendsen et al. 2002). The climate and long-term climatic variations in Svalbard are described and analysed in a number of earlier publications, for example, Birkeland (1930), Hesselberg \& Johannessen (1958), Steffensen (1969, 1982), Hisdal (1976), HanssenBauer et al. (1990), Førland et al. (1997), Winther et al. (2003), Førland et al. (2011), Nordli et al. (2014), Przybylak et al. (2014) and Przybylak et al. (2016).

The large natural variability in the Arctic, sparse station network, frequent relocations and gaps in observation periods make monitoring the long-term climate variations in Svalbard challenging (Førland \& Hanssen-Bauer 2003). Real climatic trends may be masked when analyses are based on inhomogeneous series (Hanssen-Bauer $\&$ Førland 1994; Nordli et al. 1996). To get an optimal view on long-term temperature development, it is therefore important to establish homogeneous long-term series for as many locations as possible.

At six meteorological stations on western Spitsbergen (Fig. lb) subdaily temperature measurements have been performed during parts of the period 1911-present. The temperature series from these stations have been digitized, quality controlled, gap-filled and homogeneity tested in a Norwegian, Russian and Polish collaboration. The recently digitized series have made it possible to reconstruct daily temperature series back to 1948 for the six locations. These reconstructed series provide an opportunity to scrutinize the long-term temperature variability and development along the coast and fjords of western Spitsbergen.

This paper describes the methodology used to establish complete daily series for the six stations back to 1948 . The first objective is to analyse the long-term air temperature changes along the coast and fjords of western Spitsbergen by applying the reconstructed climate series. The second objective is to study the spatial and temporal air temperature gradients and variability in the same area.

\section{Methods}

\section{Daily mean temperature}

Daily means for Barentsburg are calculated as the arithmetic mean of four daily temperature measurements in the period 1948-1965 and eight daily measurements in the period 1966-present. Daily mean temperature for Hornsund is calculated as the arithmetic mean of eight daily measurements. Daily means for Pyramiden are calculated as the arithmetic mean of four daily measurements in the period 1948-1957 and as the arithmetic mean of hourly measurements in the period 2011present. Daily mean temperature for Isfjord Radio, Svalbard Airport and Ny-Ålesund has traditionally been calculated by a formula introduced by Köppen (1888) based on three daily measurements and the daily minimum temperature, see Nordli \& Tveito (2008) for details.
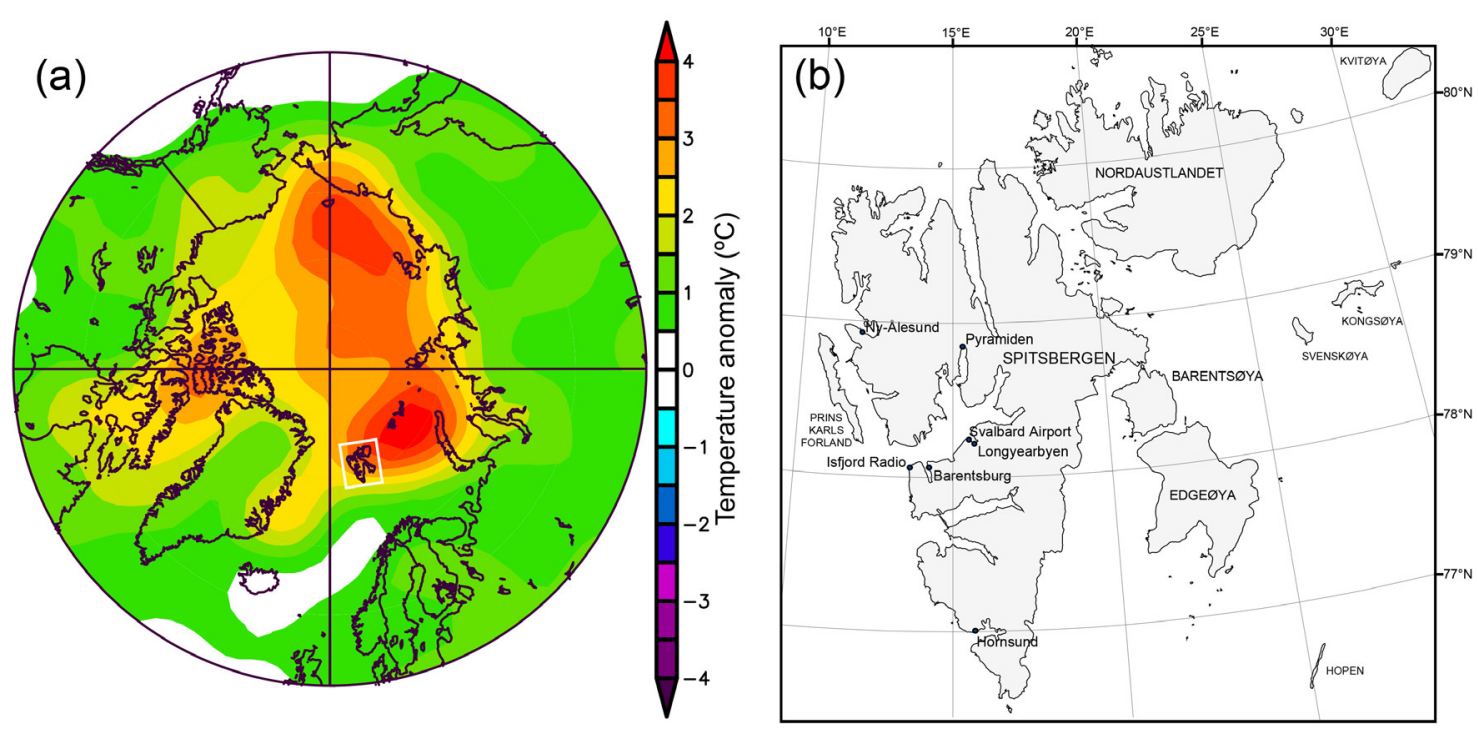

Fig. 1 Maps of the study area. (a) Average temperature $(2 \mathrm{~m})$ anomalies over the Northern Hemisphere north of $55^{\circ} \mathrm{N}$ during $2000-14$ with respect to the 1948-2000 mean, based on NCEP reanalysis data (Kalnay et al. 1996) provided by the National Oceanic and Atmospheric Administration Earth System Research Laboratory, Physical Sciences Division, Boulder Colorado (www.esrl.noaa.gov/psd/). (b) Map of Svalbard—white square in (a)—and locations of the meteorological stations used in the present study. 
For the three stations, calculation of daily means as arithmetic means of hourly measurements was introduced during the years 2005-08.

\section{Gap filling daily values in the series}

Some of the long-term temperature series at Svalbard have missing values and data gaps. For many purposes, for example, trend studies, these should be filled otherwise the trends could be unreliable. The chosen method for gap filling was regression analysis by use of series from neighbouring stations as predictors. Gaps were filled by adjusted data, $T_{C}$ (predictand), from the regression equation:

$$
T_{C}=\alpha T_{P}+C
$$

where $T_{P}$ is the daily mean temperature of a neighbouring series (predictor) and $\alpha$ and $C$ are constants calculated by the least square method.

\section{Estimation of uncertainties for the interpolated monthly means}

The standard deviation of the residual $e$ in the linear regression equation (Eqn. 1) based on daily mean temperature was used for the error estimation of the interpolated monthly mean temperatures, $\operatorname{RMSE}\left(T_{\text {month }}\right)$ :

$$
\operatorname{RMSE}\left(T_{\text {month }}\right)=\frac{e}{\sqrt{n}},
$$

where $n$ is the number of days in the month (Wilks 1995).

\section{Significance test of long-term trends}

The Mann-Kendall test is a non-parametric test of the significance of a monotonic trend in a time series. The test does not provide an estimate for the trend itself; it only tests its significance. The test is based on a relative ranking of the data where it compares each subsequent data point with all previous data points to see whether it is larger or smaller than previous data points. All the occurrences $n_{i}$ of data points smaller than previous data points are used in the calculation of the test statistic $t$, which is given by:

$$
t=\sum_{i=1}^{n} n_{i}
$$

where $n$ is the number of data points.

The null hypothesis $\mathrm{H}_{0}$ is that there is no trend in the data set. In order to reject or confirm the null hypothesis, a distribution of the test statistic is calculated as follows:

$$
u(t)=\frac{t-E(t)}{\sigma}, E(t)=\frac{n(n-1)}{4},
$$

where $E(t)$ is the expectation of $t$ and $\sigma$ is the square root of the variance $\sigma^{2}$ given by:

$$
\sigma^{2}=\frac{n(n-1)(2 n+5)}{72}
$$

If the test statistic distribution is larger than $z_{a / 2}$, where $a$ is the chosen significance level, one can reject the null hypothesis. The $z_{a / 2}$ can be found using a standard normal distribution table (Sneyers 1990).

\section{Smoothing procedures}

Low-pass filters may be used to "smooth" data series. One of these is a filter using the Gaussian distribution. By choosing a standard deviation $\sigma$ in the distribution, it is decided at what time scale the variations are smoothed. In the present article, we have chosen $\sigma=3$ in Eqn. 5, which removes variations at smaller time scales than approximately 10 data points in the time series. In a series of annual values, this means that the smoothed series illustrates variability at a decadal scale. The filtered value $G$ at data point $j$ is given by:

$$
G_{j}=\frac{\sum_{i=1}^{n} w_{i j} x_{i}}{\sum_{i=1}^{n} w_{i j}}, w_{i j}=\exp \frac{-1(i-j)^{2}}{2 \sigma^{2}},
$$

where $\sigma$ is the standard deviation, $w$ is the weight, $n$ is the number of observations in the series and $x$ is the data point. A series of filtered values is established by letting $j$ run through all data points.

\section{Wavelet analysis}

Wavelet analysis is a tool for studying the structure of the signal frequency in a time series. By plotting the coefficients from the wavelet transform in what is referred to as spectrograms, the small-scale and large-scale components of the signal can be displayed, and each component's contribution to the variability can be evaluated. Wavelet coefficients and spectrograms were calculated by a onedimensional continuous wavelet transform. The continuous wavelet transform of the function $f(x)$ with respect to the wavelet function $\psi(x)$ (the Morlet wavelet) is defined by the formula:

$$
W_{\psi}[f](y, z)=|y|^{-1 / 2} \int_{-\infty}^{\infty} f(x) \psi\left(\frac{x-z}{y}\right) d x,
$$


where $y$ is the scaling parameter and $z$ is the shift parameter. For further details, see Smolencev (2005).

\section{Continentality index}

To estimate the continentality of the Svalbard climate, the K-index proposed by Ewert (1972) has been calculated according to the formula:

$$
K=\left[A T R-\frac{(3.81 \sin \varphi+0.1)}{(38.39 \sin \varphi+7.47)}\right] 100 \%,
$$

where ATR is annual temperature range (the difference between the highest and lowest monthly mean temperature), and $\varphi$ is the geographical latitude.

\section{Data}

The most essential information about the data and the meteorological stations is presented in Table 1. Here the metadata will be presented only briefly as there have been many earlier papers that have quite comprehensive descriptions (Steffensen 1969; Nordli et al. 1996; Steffensen et al. 1996; Førland et al. 1997; Nordli 2010; Ivanov et al. 2014; Nordli et al. 2014).

Most of the series have been checked (now or earlier) for homogeneity breaks by the standard normal homogeneity test introduced by Alexandersson (1986). This is a relative homogeneity test that requires reference stations for comparison. However, there are few reference stations in Svalbard, so taking metadata into account is even more important than when working on denser networks. During some periods, the nearest stations are so remote that only metadata can be used in the homogeneity testing. Inhomogeneities in a data series might be due to instrumental changes, changed observational procedures, site relocations, changes in the environment etc. (e.g., Nordli et al. 1997).

The gaps in the daily mean temperature series were filled by adjusted data from the neighbouring stations by use of Eqn. 1 (see methods). Unfortunately, all stations have gaps during World War II, so those gaps were not possible to fill. The skill of the reconstructions was assessed by the standard deviations of the residuals, that is, the root mean square error (RMSE), and also the percentage of the variance accounted for by the regression (Supplementary Table S1). The percentage of the variance accounted for by the regression was in general largest during winter and smallest during summer. However, because of smaller variability in summer than in winter, the RMSE was lowest in summer.

The RMSE for the interpolated daily mean temperatures varied from $0.7^{\circ} \mathrm{C}$ to $2.0^{\circ} \mathrm{C}$ in winter and from $0.4^{\circ} \mathrm{C}$ to $-1.1^{\circ} \mathrm{C}$ in summer, whereas the variance accounted for by the regression varied from $93 \%$ to $99 \%$ in winter and from $62 \%$ to $96 \%$ during summer (Supplementary Table S1). The RMSE for the monthly mean temperature was

Table 1 Metadata for the daily mean temperature series. Station names, period of available daily observations, period of daily reconstructed series (reconstructions and observations), relocations $\left(H_{s}=m\right.$ a.s.l., $D=$ distance in metres, time of the event), screen change (time and type). See Supplementary file for more information about screen types.

\begin{tabular}{|c|c|c|c|c|}
\hline Name & Period of daily observation series & Period of daily reconstructed series & Relocations: $H_{s}$; $D$; time & Screen change and type \\
\hline \multirow[t]{2}{*}{ Hornsund } & 01.07.1978-present & 01.09.1934-31.07.1941 & $11 ;-; 01.07 .1978$ & 07.1978: MI-1933 \\
\hline & & $01.09 .1946-31.12 .2015$ & & 01.2001: Vaisala, DTR13 \\
\hline \multirow[t]{5}{*}{ Isfjord Radio } & 01.09.1934-30.06.1941 & 01.09.1934-31.07.1941 & $6 ;-; 01.09 .1934$ & 09.1934: MI-1930 \\
\hline & $01.09 .1946-30.06 .1976$ & $01.09 .1946-31.12 .2015$ & 6; 60;09.06.1958 & 1939: MI-1933 \\
\hline & 01.01.1997-05.02.2002 & & 6; 5; 20.06.1964 & 1946: MI-1930 \\
\hline & $20.06 .2002-06.12 .2004$ & & 7; ?; 10.09.2014 & 08.1951: Ml-1933 \\
\hline & 10.09.2014-present & & & 09.2014: MI-2001B \\
\hline \multirow[t]{3}{*}{ Barentsburg $^{a}$} & 01.01.1932-31.12.1935 & 01.01.1940-31.07.1941 & $70 ;-; 01.01 .1940$ & 01.1932: Selianinov \\
\hline & 01.01.1940-31.07.1941 & $01.09 .1946-31.12 .2015$ & 22; ?; 01.06.1978 & \\
\hline & 01.12.1947-present & & 74; ?; 01.02.1984 & \\
\hline \multirow[t]{2}{*}{ Svalbard Airport } & 01.08.1975-present & $01.01 .1957-31.12 .2015$ & $28 ;-; 01.08 .1975$ & 08.1975: MI-1933 \\
\hline & & & $28 ; 150 ; 05.10 .2010$ & 10.2010: MI-2001B \\
\hline \multirow[t]{2}{*}{ Pyramiden } & 01.01.1948-15.05.1957 & 01.01.1940-31.07.1941 & $9 ;-; 01.01 .1948$ & 01.01.1948: Selianinov \\
\hline & 23.07.2011-present & $01.12 .1947-31.12 .2015$ & $9 ; 0 ; 23.07 .2011$ & 23.07.2011: MI-2001B \\
\hline \multirow[t]{4}{*}{ Ny-Ålesund ${ }^{b}$} & 01.01.1969-present & 01.09.1934-31.07.1941 & $42 ;-; 01.01 .1969$ & 01.1969: MI-1933 \\
\hline & & $01.09 .1946-31.12 .2015$ & 8; 2k; 21.07.1974 & 06.1982: MI-1946 \\
\hline & & & $8 ; 100 ; 08.2000$ & 08.1994: MI-1974 \\
\hline & & & & 2007: MI-2001B \\
\hline
\end{tabular}

${ }^{a}$ Missing months: 07.1941-11.1947; 10.1972; 01.1973; 01-04.1977; 07.1981; 08.1985; 12.1985; 10-12.1987; 08-09.1988; 07-12.1991. There are daily data for Barentsburg for the period 1936-1940 but they are not digitized. ${ }^{b}$ Comprises the stations Ny-Ålesund I and Ny-Ålesund II. 
assessed using Eqn. 2. This means that the highest RMSE in the daily means of about $2^{\circ} \mathrm{C}$ is reduced to about $0.5^{\circ} \mathrm{C}$ for the corresponding monthly means, whereas the lowest RMSE in the daily means is of the same size as the uncertainty of the thermometers or sensors. The regression coefficient ( $\alpha$ in Table Sl) accounts for the different continentality between the series, $\alpha<1$ for the maritime series and $\alpha>1$ for the continental series.

A more detailed account of each stations metadata, homogeneity and gap filling procedure can be found in the Supplementary file.

\section{Results and discussion}

\section{Long-term temperature development}

The climate in Svalbard is undergoing rapid changes, as pointed out in the introduction, but how are these changes seen in the spatial temperature pattern? The new reconstructed series provide an opportunity to answer this question by studying local temperature gradients from outer to inner parts of Isfjorden and from south to north along the coast of western Spitsbergen in addition to perform an analysis of climate variability and change. The first step in the analysis was to examine the annual and seasonal long-term temperature development at the six meteorological stations discussed in this study (Fig. 2). The filtered reconstructed temperature series reveals the decade-scale variability in the time series. The monthly temperature series from Svalbard Airport has previously been extended back to 1898 (Nordli et al. 2014) and has been included in Fig. 2 .

The time series show a similar pattern in all seasons. The coldest periods can be found in the 1910s and 1960s in all seasons. The early 20th century warming (e.g., Brönnimann 2009) can be seen in the 1920s and 1930s. Another warm period can be seen in the 1950s. However, the latest decades show a distinctive warming and the filtered curves show that the last 15 years are the warmest in the instrumental record for all stations and all seasons. An interesting feature in the autumn figure is that the warm periods in the 1930s and 1950s were almost as warm as the current warm period. This will affect the significance and size of the trends in autumn, as will be seen in later paragraphs.

The temperature development was further scrutinized by wavelet analysis, looking for the most powerful variations on different time scales during the period 19472014. Not unexpected, the highest power was located in the annual temperature cycle, but high power was also detected in wavelengths of about 15-20 years, corresponding roughly to the Gaussian decadal filter
(Supplementary Fig. S1). However, the decadal variations seem to weaken at the end of the period. Also in winter (January) the wavelengths of 15-20 years are the most powerful, whereas in summer (July) the most powerful wavelengths are longer, more than 25 years.

The current climatological standard normal period is 1961-1990 (WMO 1996). Figure 3 shows that for the most recent 30-year period (1986-2015), the average monthly temperatures during November-March are more than $2^{\circ} \mathrm{C}$ higher than the 1961-1990 normals. The figure demonstrates a distinct annual pattern with highest deviations during winter and lowest during summer. The only exception from the rather smooth annual pattern is the month of October, and the jump from October to November is noteworthy. The main reason for the enhanced warming during winter is probably the reduced sea-ice cover along the western coast of Spitsbergen.

\section{Linear trends}

To quantify the temperature development at the stations, linear trends were calculated. The linear trends for the reconstructed time series are positive for all seasons (Table 2). For Svalbard Airport, the linear trend for the annual means of the full-length reconstructed series is $0.3^{\circ} \mathrm{C} /$ decade and significant on a $5 \%$ level. This trend is approximately 3.5 times as large as the linear trend in the global mean surface temperature in the period 19012012 (Hartmann et al. 2013). This is consistent with Hartmann et al. (2013) which stated that areas north of $65^{\circ}$ have a more pronounced warming than southern areas. The trend is also almost four times as large as the linear trend in the mean annual temperature at Troms $\varnothing$ in northern Norway in the period 1901-2015, which is consistent with the spatial pattern in Fig. la. The linear trends for a common data period 1948-2015 enable a comparison of the stations' trends (Supplementary Table S3). There is a positive significant trend in all seasons except for autumn. The largest trends can be found during winter and spring, the largest one being $0.7^{\circ} \mathrm{C} /$ decade for Svalbard Airport in winter. The time series start in a warm period with quite high temperatures, especially during autumn (Fig. 2), and this, of course, influences the significance of the trends.

Table $2 \mathrm{~b}$ gives the linear trends for the period 1979-2015 for the four stations that have observations in this period: Hornsund, Barentsburg, Svalbard Airport and Ny-Ålesund (compare to Table 1). The trends are all positive and significant on a $5 \%$ level, and show a stronger warming compared to the trends in Table $2 \mathrm{a}$. The largest trends are found in winter, the largest one being $2.3^{\circ} \mathrm{C} /$ decade for 

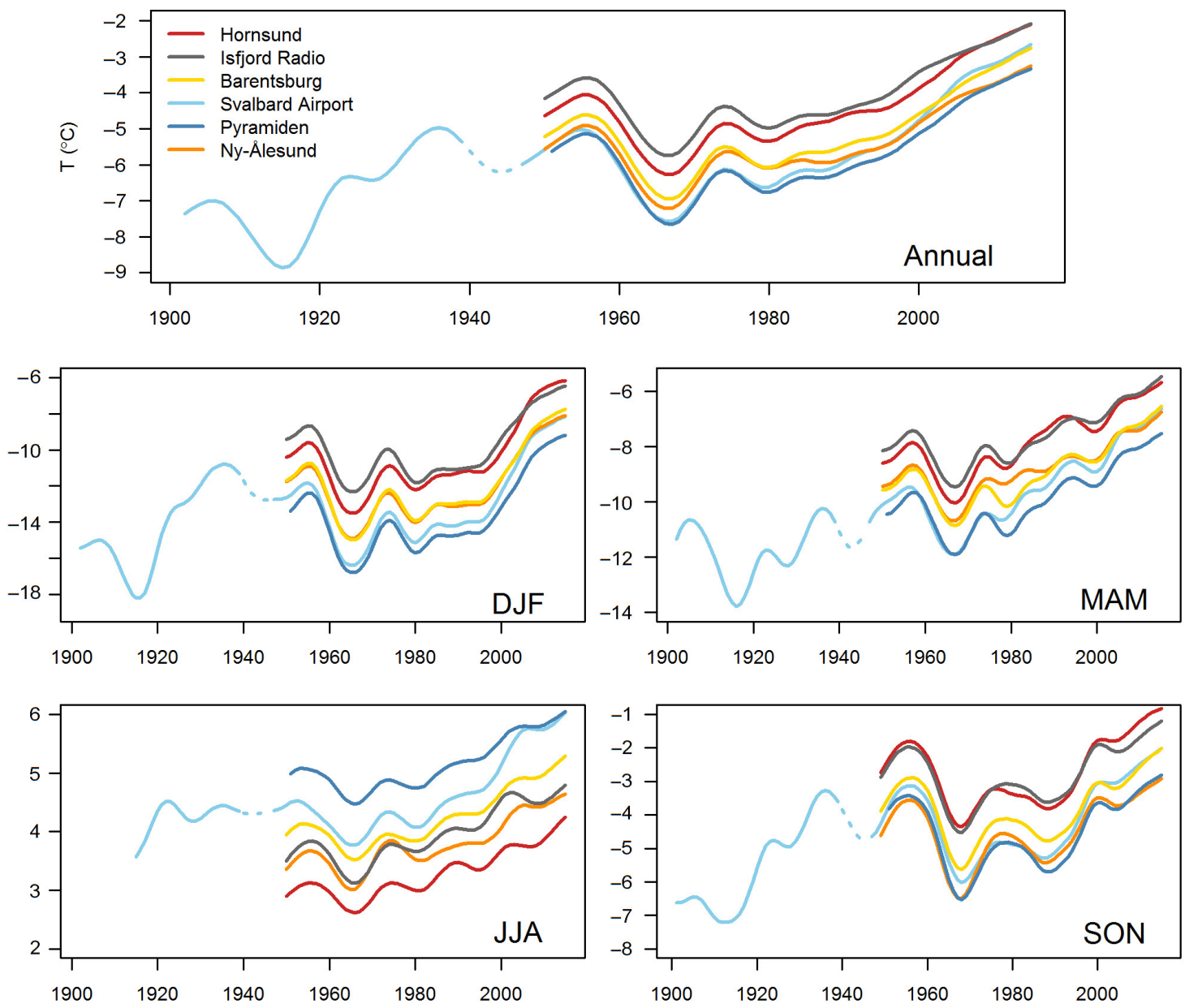

Fig. 2 Long-term annual and seasonal mean temperatures $\left({ }^{\circ} \mathrm{C}\right)$ for the reconstructed series from Hornsund, Isfjord Radio, Barentsburg and Ny-Ålesund (1950-2015), Pyramiden (1951-2015) and Svalbard Airport (1902-2015). The data are filtered by a Gaussian filter with a standard deviation of three years. The data from Svalbard Airport during the Second World War are marked by a dotted line to show that the data are uncertain and interpolated using a different method than the rest of the data (Nordli et al. 2014). The end of the curves is not significant because parts of the Gaussian weighting coefficients lie on unknown future observations. For 2015 , this part is $38 \%$, for $2009,5 \%$.

Svalbard Airport. It is more than two times as large as the trends for spring and autumn in the same period.

When comparing trends from western Spitsbergen to the rest of the Arctic, the same pattern showing a significant warming in the latest decades and a more pronounced warming in winter is observed. Hanna et al. (2012) presented an updated analysis of monthly means of daily mean, maximum and minimum temperature from coastal meteorological stations on Greenland. Trends for the period 1981-2011 were positive and mostly significant for all stations and all seasons. As for Spitsbergen, the greatest warming was observed in winter and with trends as high as $2.8^{\circ} \mathrm{C} /$ decade on the west coast. Przybylak (2007) presented an analysis of spatial and temporal changes in mean seasonal and annual surface air temperature from up to 35 Arctic stations in the period
1936-2005. The start year of this period lies in the peak of the early 20 th century warming and lack the latest decade as well. Therefore, few significant trends were observed.

In addition to the significance levels from the linear model, a sequential Mann-Kendall test was performed to further assess the significance of the trends (Supplementary Fig. S2). The test shows how the significance of the trend changes as the start year of the series changes. By beginning the time series in 2014 and recalculating the test statistic for every year added to the time series backwards in time, one can see how the significance changes when the start year is in a warm period versus in a cold period. According to this test, the trend of the annual means is significant on a $5 \%$ significance level for all stations. The longer time series from Svalbard Airport and Ny-Ålesund are significant on a 5\% level even when 


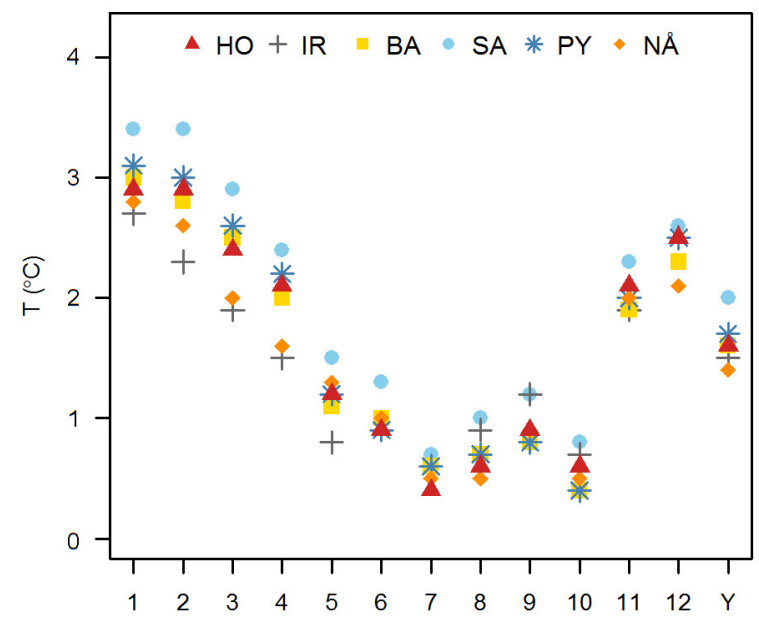

Fig. 3 Difference $\left({ }^{\circ} \mathrm{C}\right)$ between the latest 30 year average (1986-2015) and the 1961-1990 normal for each month (1-12) and year (Y) for Hornsund (HO), Isfjord Radio (IR), Barentsburg (BA), Svalbard Airport (SA), Pyramiden (PY) and Ny-Ålesund (NÅ).

the start year of the series is in a warm period such as the 1930s. The same can be said for spring and summer, indicating robust trends. For winter, however, a start year in the warm period during the 1920s and 1930s would not produce a significant trend. For autumn, a start year in the 1930s or late 1940s/early 1950s would not give a significant trend, which is in agreement with Table 2a and Supplementary Table S3.

Since the 1980s Svalbard Airport seems to have a larger temperature increase than the rest of the stations. Table 2b shows that for the period 1979-2015, Svalbard Airport has the largest trends for all seasons. According to Fig. 2, Svalbard Airport and Pyramiden start out as the coldest stations in the annual time series, but Svalbard Airport is distinctively warmer than Pyramiden by the end of the time series. From around year 2000, it also becomes warmer than Barentsburg and Ny-Ålesund. (This can also be seen in Fig. 7, where Svalbard Airport has a larger increase in number of days with temperatures above $0^{\circ} \mathrm{C}$ and $5^{\circ} \mathrm{C}$ than the rest of the stations.)
The reason for this enhanced warming at Svalbard Airport is not obvious. As concluded by Nordli et al. (2014), no homogeneity breaks were detected when comparing the series to nearby stations established in the 1990s. Possible explanations for the larger temperature increase might be fewer inversions, reduced sea ice and higher sea-surface temperatures in Isfjorden, or effects from changes in infrastructure at the airport. To investigate the local climate around the Svalbard Airport weather station, supplementary temperature stations were established in September 2015 in the neighbouring area.

\section{Spatial gradients}

A west-east transect from the outer to inner parts of Isfjorden of the 1961-1990 normals for February, April, July and October can be seen in Fig. 4 (see Supplementary Table S4 for all months). The figure demonstrates that Svalbard Airport and Pyramiden are the two coldest stations in winter, spring and autumn while they are the two warmest ones in summer. There seems to be a more pronounced difference in continentality in winter (ice season) than in summer. The transect from south to north along the coast of western Spitsbergen with Hornsund, Isfjord Radio and Ny-Ålesund shows that the northern part of Svalbard is coldest in winter, spring and autumn. In summer, however, Hornsund in the south is the coldest station. See also Fig. 2. This might be due to more sea ice around Hornsund in summer than at the other stations.

The continentality of the climate can be quantified by a continentality index (K-index; see Eqn. 7). Western Spitsbergen has a maritime Arctic climate with a K-index roughly between $30 \%$ and $50 \%$ (see Supplementary Table S8). When comparing the stations, Pyramiden is found to have the highest K-index (48\%) for the period 1948-2014 while Hornsund and Isfjord Radio has the lowest K-index (33\%) in the same period (Supplementary Table S8), and have a somewhat more pronounced maritime climate.

Table 2 Linear trend ( ${ }^{\circ} \mathrm{C} /$ decade) for (a) the full-length reconstructed temperature series from Hornsund, Isfjord Radio and Ny-Ålesund (09.1934-2015), Barentsburg (1933-2015), Svalbard Airport (09.1898-2015 [1912 - 2015 for JJA]) and Pyramiden (1948-2015) (all stations have missing values 06.1941-08.1946) and (b) the temperature series from Hornsund, Barentsburg, Svalbard Airport and Ny-Ålesund for the period 1979-2015. Numbers in boldface denote a trend significant at the $5 \%$ level.

\begin{tabular}{|c|c|c|c|c|c|c|c|c|c|c|}
\hline \multirow[b]{2}{*}{ Station } & \multicolumn{5}{|c|}{ (a) Full-length series } & \multicolumn{5}{|c|}{ (b) 1979-2015 } \\
\hline & Year & DJF & MAM & JJA & SON & Year & DJF & MAM & $J \mathrm{JA}$ & SON \\
\hline Hornsund & 0.26 & 0.31 & 0.38 & 0.14 & 0.07 & 1.03 & 2.00 & 0.79 & 0.33 & 0.95 \\
\hline Isfjord Radio & 0.20 & 0.14 & 0.31 & 0.16 & 0.07 & & & & & \\
\hline Barentsburg & 0.19 & 0.23 & 0.30 & 0.14 & 0.05 & 1.06 & 2.04 & 1.02 & 0.43 & 0.75 \\
\hline Svalbard Airport & 0.28 & 0.35 & 0.41 & 0.14 & 0.26 & 1.29 & 2.34 & 1.07 & 0.63 & 1.04 \\
\hline Pyramiden & 0.36 & 0.60 & 0.45 & 0.19 & 0.16 & & & & & \\
\hline Ny-Ålesund & 0.16 & 0.15 & 0.26 & 0.16 & 0.11 & 0.96 & 1.96 & 0.72 & 0.40 & 0.69 \\
\hline
\end{tabular}



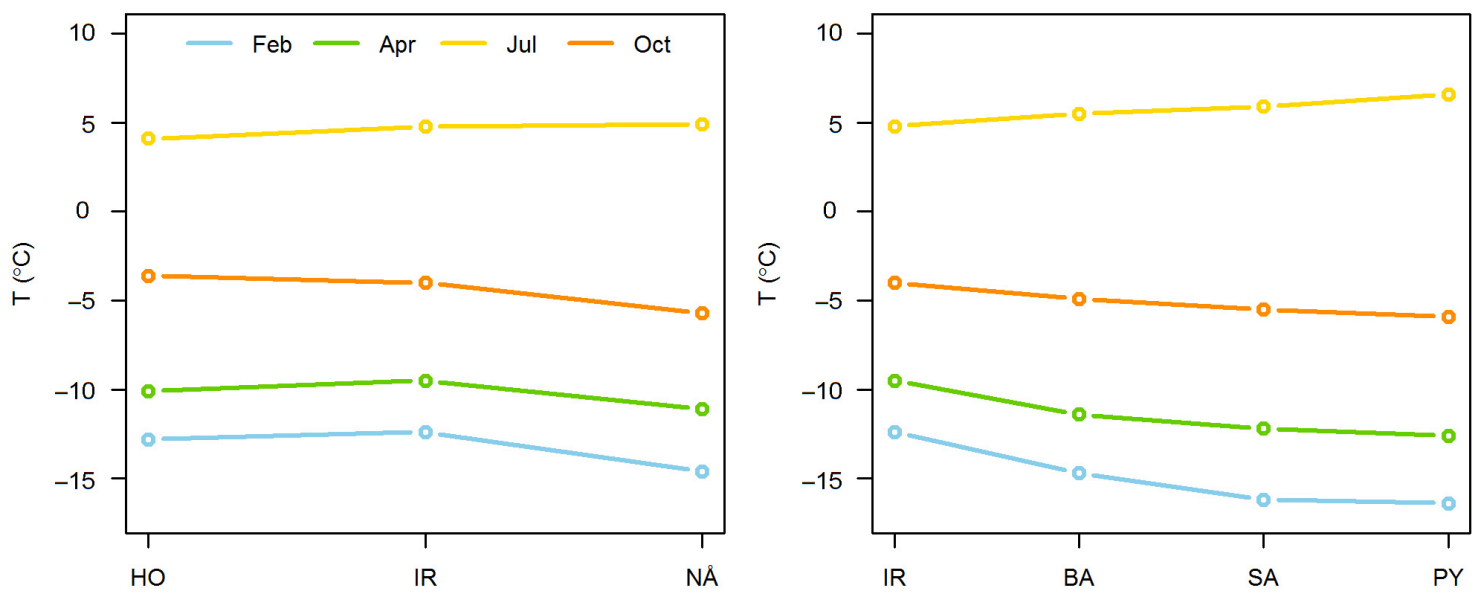

Fig. 4 The 1961-1990 normal temperature $\left({ }^{\circ} \mathrm{C}\right)$ for February, April, July and October for a south-north transect in the left panel and a west-east transect in the right panel for the stations Hornsund (HO), Isfjord Radio (IR), Barentsburg (BA), Svalbard Airport (SA), Pyramiden (PY) and Ny-Ålesund (NÅ).

For comparison, eastern Siberia has a K-index of 140\% while extreme maritime climates have a K-index of $0 \%$ (Ewert 1997). It can be seen in Fig. 5 and Supplementary Table S8 that the K-index varies and is higher in colder periods (e.g., the 1960s) than in warmer periods (e.g., the 1950s).

From Fig. 5, it is evident that large changes in the Kindex have occurred in Spitsbergen during the most recent decades. The larger temperature increase in winter and spring (Table 2) has led to a smaller temperature difference between summer and winter, thus reducing the annual variability.

\section{Temporal variability}

A decrease in variability is also observed when studying extreme temperatures. In addition to daily mean

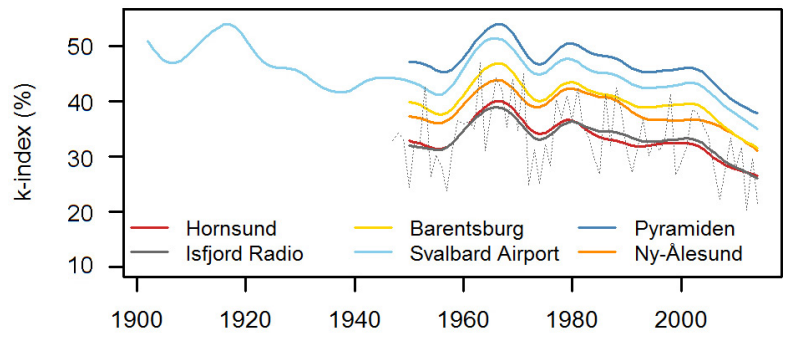

Fig. 5 K-index (\%) of the reconstructed series from Hornsund, Isfjord Radio, Barentsburg, Pyramiden and Ny-Ålesund in the period 1950-2014 and Svalbard Airport in the period 1902-2014. The time series have been filtered using a Gaussian filter with a standard deviation of three years. The unfiltered series from Isfjord Radio is also included (grey dotted line). The end of the filtered curves is not significant because parts of the Gaussian weighting coefficients lie on unknown future observations. temperature, daily maximum and minimum temperature is available for the stations Hornsund, Barentsburg, Svalbard Airport and Ny-Ålesund. The changes in the annual mean maximum and minimum temperature show a larger increase in minimum temperature extremes than in maximum temperature extremes (Supplementary Fig. S3 and Table S7). The linear trend for annual mean minimum temperature for Hornsund, Barentsburg, Svalbard Airport and Ny-Ålesund for the period 19792015 is on average $0.3^{\circ} \mathrm{C}$ larger per decade than for maximum temperature.

These results are consistent with the findings of Hartmann et al. (2013) where the shift towards higher values in the probability distribution functions of daily maximum and minimum temperatures over the globe has been greater for minimum temperature. A larger warming in daily minimum temperature than in daily maximum temperature was also observed in the Greenland data series by Hanna et al. (2012), mainly during winter.

The inter-annual variability (Fig. 6) has decreased in winter and spring. Summer and autumn, on the other hand, show no significant changes. The largest variability occurs in winter, spring and autumn, so these three seasons give the largest contribution to the pattern in the annual series. Donat \& Alexander (2012) observed that in addition to a greater change in the global daily minimum temperature extremes compared to the daily maximum temperature extremes, the variance of both parameters seemed to have decreased from the 1951-1980 period to the 1981-2010 period in the extra-tropical area $\left(30^{\circ} \mathrm{N}-\right.$ $\left.90^{\circ} \mathrm{N}\right)$, although it was pointed out that there were regional differences in this area. 

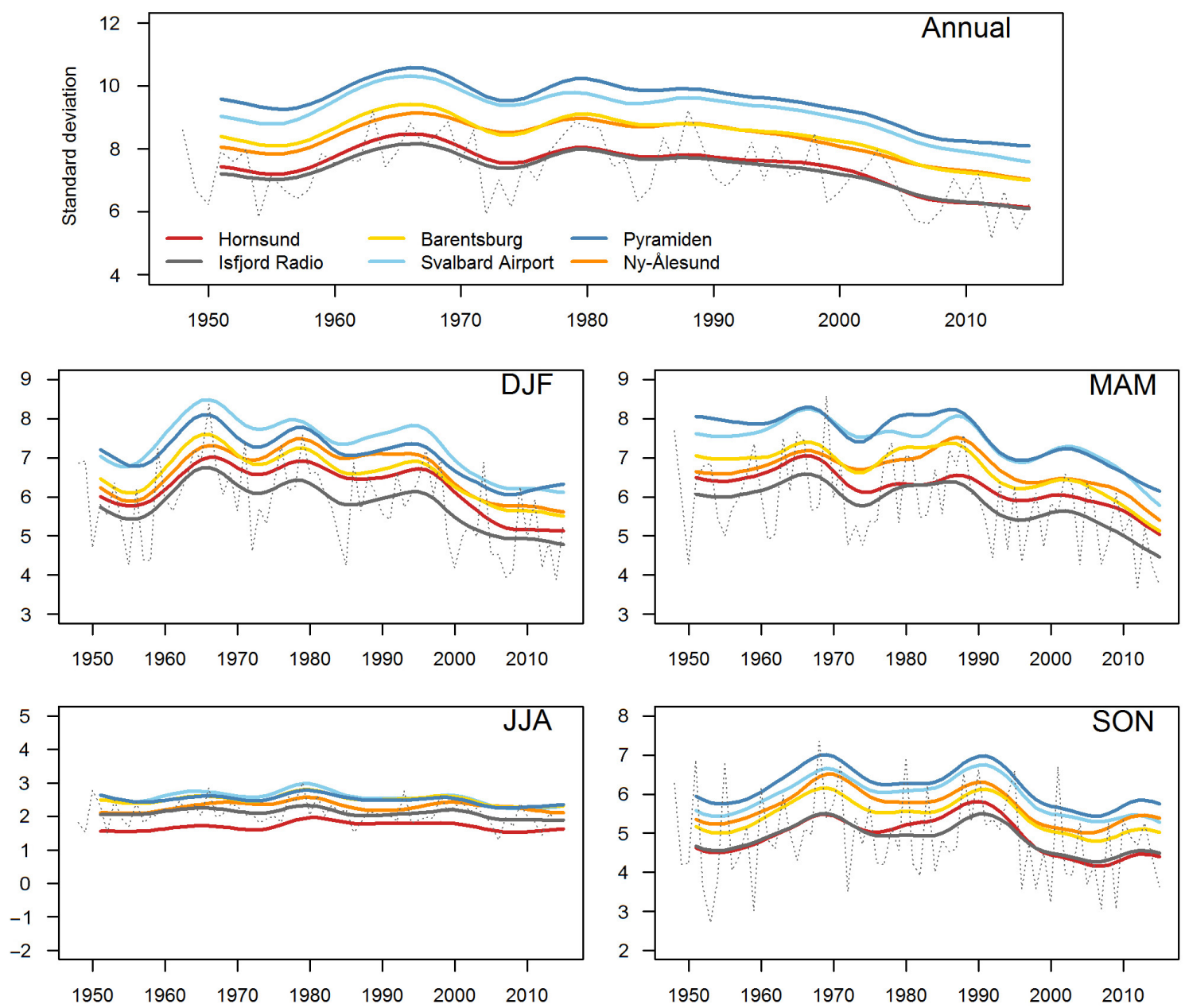

Fig. 6 Inter-annual temperature variability between 1948 and 2015. Standard deviation for annual and seasonal series calculated from the daily series of Hornsund, Isfjord Radio, Barentsburg, Svalbard Airport and Ny-Ålesund. The time series have been filtered using a Gaussian filter with a standard deviation of three years to show variability on decadal time scale. The unfiltered series from Isfjord Radio is also included (grey dotted line). The end of the filtered curves is not significant because parts of the Gaussian weighting coefficients lie on unknown future observations.

\section{Threshold statistics}

The daily data set provides an opportunity to examine threshold statistics. Fig. 7 displays the number of days per year with temperatures exceeding various thresholds for Isfjord Radio and in addition the smoothed curves for all stations. The pattern is clear: fewer cold days and more warm days. This is also evident in Supplementary Table S6, which shows the difference between the 1986-2015 and 1961-1990 periods for the four different thresholds. An interesting feature shown in Fig. 7 is that the number of days with a temperature larger than $0^{\circ} \mathrm{C}$ in the warm period in the 1950s is at the same level as the most recent years (especially in 1954, 1957 and 1959 there are many events). This picture cannot be seen for the other thresholds $\left(-15,-10\right.$ and $\left.5^{\circ} \mathrm{C}\right)$; for instance, the number of days with temperature above $5^{\circ} \mathrm{C}$ is higher in the most recent years than in the 1950s. The 1950s contained a high number of especially warm days in autumn (not shown).

Hornsund and Svalbard Airport show a more distinct change in the threshold statistics than the other four stations. Hornsund shows a larger increase in warm days $\left(T>0\right.$ and $T>5^{\circ} \mathrm{C}$ ) in particular in the latest few years while Svalbard Airport shows a larger increase in warm days from the mid-90s. The decrease in cold days is more uniform; however, Svalbard Airport has a stronger decrease in number of days with temperature below $-10^{\circ} \mathrm{C}$.

The development in the extreme temperatures shows the same pattern as the mean temperature. The number of days with a maximum temperature above $7^{\circ} \mathrm{C}$ (corresponding to the 95th percentile) has increased at all stations. The number of days with minimum temperature below $-20^{\circ} \mathrm{C}$ has decreased drastically (Supplementary Fig. S3). At Svalbard Airport, it ranges from 125 days in 

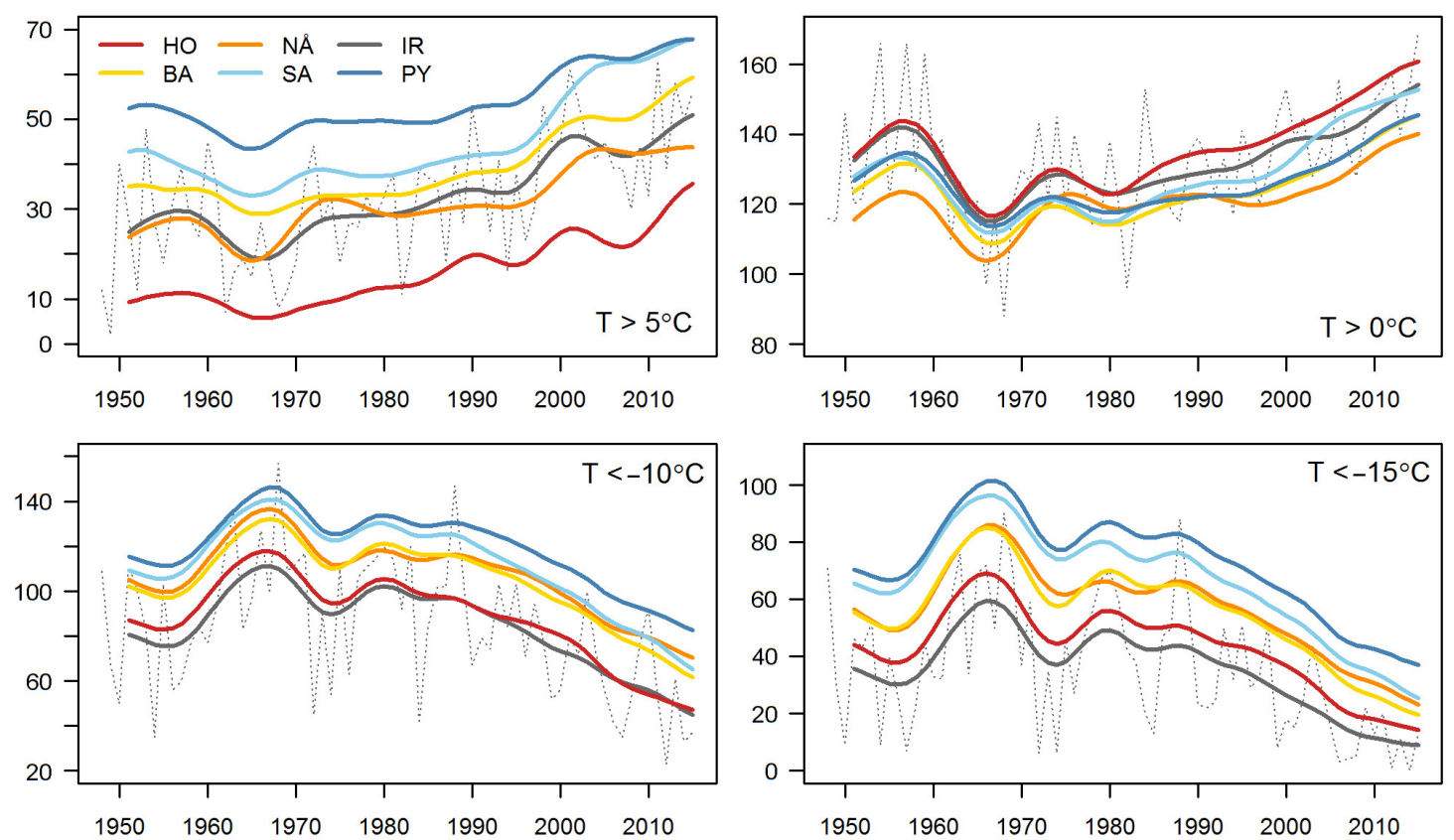

Fig. 7 Gauss filtered series of the number of days per year with mean temperature higher or lower than $5,0,-10$ and $-15^{\circ} \mathrm{C}$ for $\mathrm{Hornsund}(\mathrm{HO})$, Isfjord Radio (IR), Barentsburg (BA), Svalbard Airport (SA), Pyramiden (PY) and Ny-Ålesund (NÅ). The data period is 1948-2015. The unfiltered series from Isfjord Radio is also included (grey dotted line). The end of the filtered curves is not significant because parts of the Gaussian weighting coefficients lie on unknown future observations.

1988 to 2 days in 2012 and 2014. Our results support a study by Hansen et al. (2014) that found an increased frequency of above-zero temperatures and heavy rainon-snow events in winter on western Spitsbergen.

\section{Influence of sea ice}

The six meteorological stations in this study are all situated adjacent to the coast and fjords. In addition to radiation budget and large-scale atmospheric circulation, the main drivers of the surface temperature in the Arctic are the areal extent and concentration of the Arctic sea-ice cover and the associated sea-surface temperature, especially in winter (Benestad et al. 2002; Screen et al. 2012). The sea-ice extent in the Svalbard area has been mapped by the Norwegian Ice Service (www.polarview.met.no) since the winter of 1969/70. The charts are compiled from satellite images, as well as ship and aircraft observations. More details are found in Hughes \& Wagner (2015).

In Fig. 8, two periods were chosen to provide an overview of the sea-ice conditions in the last 30-year climatological average period (1981-2010) and over the past 10 years (2006-2015). The figure shows the monthly sea-ice minimum, average and maximum extents at $40 \%$ ice concentration for the month of typical maximum ice extent (April) and minimum extent (September). The maps demonstrate that during late summer there is no ice in the fjords of western Spitsbergen (Fig. 8c, d). During 1981-2010, Isfjorden in average years was covered by sea ice in April (Fig. 8a), while during the latest 10 years it is very rare to find sea ice in this fjord in late winter (Fig. 8b).

The fact that the sea-ice cover in the fjords on western Spitsbergen has decreased in the latest decades and that there recently have been years with virtually no sea-ice cover during some winters is supported by other studies (Nilsen et al. 2008; Zhuravskiy et al. 2012; Hegseth \& Tverberg 2013; Muckenhuber et al. 2016). Pavlov et al. (2013) showed that fjord systems along western Spitsbergen went from an Arctic state to be strongly influenced by Atlantic Water after winter 2006 (Cottier et al. 2007). The advection of Atlantic Water influenced the fjord thermodynamics and sea-ice cover and resulted in more open water and larger ocean-to-atmosphere heat flux.

Figure 8 demonstrates that the six stations have different sea-ice conditions in the winter season and, consequently, they have been exposed to different changes in the sea-ice cover (Svendsen et al. 2002; Nilsen et al. 2008; Hegseth \& Tverberg 2013; Muckenhuber et al. 2016). This may contribute to the somewhat different development in air temperature at the stations. An example is, of course, Svalbard Airport, which has shown a stronger temperature increase than the other stations. Another example is Hornsund, which has a larger trend than the other marine 


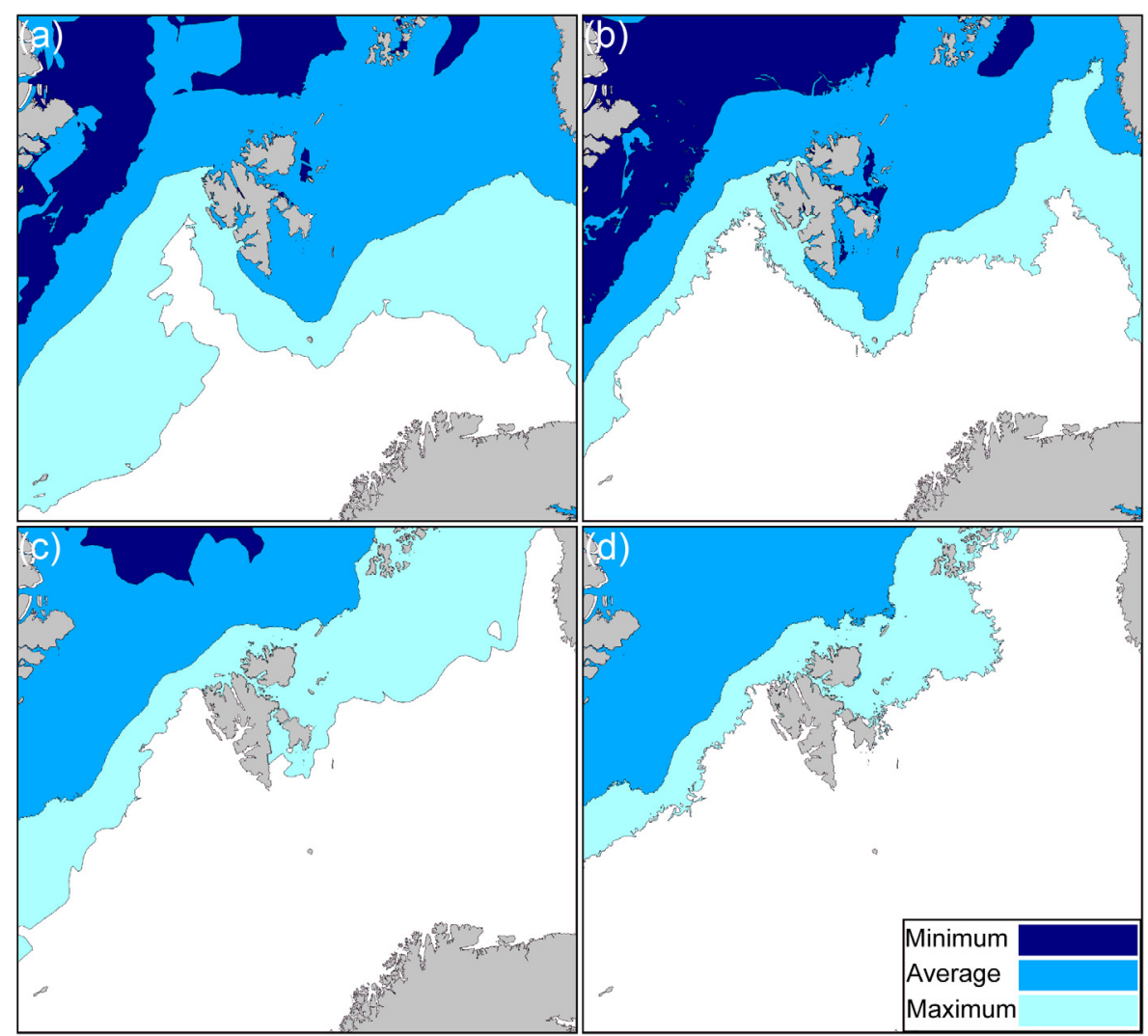

Fig. 8 The minimum, average and maximum ice extents are shown for (a, b) April and (c, d) September for (a, c) 1981-2010 and (b, d) 2006-2015 at $40 \%$ ice concentration.

stations Isfjord Radio and Ny-Ålesund in spring and autumn (Table 2). Hornsund also has a more pronounced warming in the number of warm days (Fig. 7) compared to other stations. This might be due to more open water around the station in the most recent years.

\section{Conclusions}

The recent large-scale warming in the Arctic is also observed on western Spitsbergen. The most recent years are the warmest years in the 100-year instrumental records, and the largest warming is seen in winter and spring. There is a positive and statistically significant trend in the annual times series for all six meteorological stations. The linear trend for Svalbard Airport in the period $1898-2015$ is $0.3^{\circ} \mathrm{C} /$ decade for the annual series. The last 37 years show a larger warming with linear trends of $1.3^{\circ} \mathrm{C} /$ decade for the annual series from Svalbard Airport and $2.3^{\circ} \mathrm{C} /$ decade in winter.

Threshold statistics show a decrease in the number of cold days per year and an increase in the number of warm days. The larger warming in winter gives a larger change in the number of cold days per year than in the number of warm days. It also gives a decreasing interannual variability because of a smaller temperature difference between winter and summer.

The northernmost station Ny-Ålesund and the stations located in the inner parts of Isfjorden are the coldest sites in winter, spring and autumn. In summer, however, Hornsund in the south is the coldest station, probably because of more lingering sea ice than at the other stations. There is a more pronounced continental climate at the stations in winter when sea ice is present. In the ice-free season, the open fjords contribute to a more maritime climate resulting in weaker temperature gradients along the coast and fjords.

Sea-ice cover and the associated sea-surface temperature have large influence on the air temperature. Different changes in sea-ice conditions at the stations have given a somewhat different development in air temperature at the stations, especially in the last 10 years. An example is a larger warming at Svalbard Airport because of more open water. 


\section{Acknowledgements}

The authors thank Nicholas E. Huges (Norwegian Meteorological Institute) for kindly providing sea-ice maps. The authors also thank two anonymous reviewers for helpful and constructive comments. The Research Council of Norway (ISFJORDEN project: POLARPROG project grant no. 227027) and the Polish-Norwegian Research Fund and Norway Grants (AWAKE [PNRF-22-A I-1/07] and AWAKE-2 [Pol-Nor/198675/17/2013] projects) are acknowledged for financially supporting the work behind this study. The research work of PW was supported by a grant funded by the Polish National Science Centre by decision no. DEC-2012/07/B/ST10/04002.

\section{References}

Alexandersson H. 1986. A homogeneity test applied to precipitation data. Journal of Climatology 6, 661-675.

AMAP 2012. Arctic climate issues 2011: changes in Arctic snow, water, ice and permafrost. Oslo: Arctic Monitoring and Assessment Programme.

Benestad R.E., Hanssen-Bauer I., Skaugen T.E. \& Førland E.J. 2002. Associations between sea-ice and the local climate on Svalbard. DNMI Klima 07/02. Oslo: Norwegian Meteorological Institute.

Bindoff N.L., Stott P.A., AchutaRao K.M., Allen M.R., Gillett N., Gutzler D., Hansingo K., Hegerl G., Hu Y., Jain S., Mokhov I.I., Overland J., Perlwitz J., Sebbari R. \& Zhang X. 2013. Detection and attribution of climate change: from global to regional. In T.F. Stocker et al. (eds.): Climate change 2013. The physical science basis. Contribution of Working Group $I$ to the fifth assessment report of the Intergovernmental Panel on Climate Change. Pp. 867-952. Cambridge: Cambridge University Press.

Birkeland B.J. 1930. Temperaturvariationen auf Spitzbergen. (Temperature variations on Spitsbergen.) Meteorologische Zeitscrift 47, 234-236.

Brönnimann S. 2009. Early twentieth-century warming. Nature Geoscience 2, 735-736.

Collins M., Knutti R., Arblaster J., Dufresne J.-L., Fichefet T., Friedlingstein P., Gao X., Gutowski W.J., Johns T., Krinner G., Shongwe M., Tebaldi C., Weaver A.J. \& Wehner M. 2013. Long-term climate change: projections, commitments and irreversibility. In T.F. Stocker et al. (eds.): Climate change 2013. The physical science basis. Contribution of Working Group I to the fifth assessment report of the Intergovernmental Panel on Climate Change. Pp. 1029-1136. Cambridge: Cambridge University Press.

Cottier F.R., Nilsen F., Inall M.E., Gerland S., Tverberg V. \& Svendsen H. 2007. Wintertime warming of an Arctic shelf in response to large-scale atmospheric circulation. Geophysical Research Letters 34, L10607, doi: http://dx.doi.org/10.1029/ 2007GL029948

Donat M.G. \& Alexander L.V. 2012. The shifting probability distribution of global daytime and night-time temperatures.
Geophysical Research Letters 39, L14707, doi: http://dx.doi.org/ 10.1029/2012GL052459

Ewert A. 1972. O obliczaniu kontynentalizmu termicznego klimatu. (Calculating thermic continentality of climate.) Przeglad Geogrograficzny 44, 273-288.

Ewert A. 1997. Kontynentalizm termiczny klimatu regionów polarnych. (Thermic continentality of the climate of the polar regions.) Problemy Klimatologii Polarnej 7, 55-64.

Førland E., Hanssen-Bauer I. \& Nordli Ø. 1997. Climate statistics $\theta$ longterm series of temperature and precipitation at Svalbard and Jan Mayen. DNMI Klima 21/97. Oslo: Norwegian Meteorological Institute.

Førland E.J., Benestad R., Hanssen-Bauer I., Haugen J.E. \& Skaugen T.E. 2011. Temperature and Precipitation Development at Svalbard 1900-2100. Advances in Meteorology 2011, article no. 893790, doi: http://dx.doi.org/10.1155/2011/ 893790

Førland E.J. \& Hanssen-Bauer I. 2003. Past and future climate variations in the Norwegian Arctic: overview and novel analyses. Polar Research 22, 113-124.

Graversen G.G., Langen L.L. \& Mauritsen T. 2014. Polar amplification in CCSM4: contributions from the lapse rate and surface albedo feedback. Journal of Climate 27, 4433-4450.

Hanna E., Mernild S.H., Cappelen J. \& Steffen K. 2012. Recent warming in Greenland in a long-term instrumental (1881-2012) climatic context: I. Evolution of surface air temperature records. Environmental Research Letters 7, article no. 045404, doi: http://dx.doi.org/10.1088/1748-9326/7/4/ 045404

Hansen B.B., Isaksen K., Benestad R., Kohler J., Pedersen Å.Ø., Loe L.E., Coulson S.J., Larsen J.O. \& Varpe Ø. 2014. Warmer and wetter winters: characteristics and implications of an extreme weather event in the High Arctic. Environmental Research Letters 9, article no. 114021, doi: http://dx. doi.org/10.1088/1748-9326/9/11/114021

Hanssen-Bauer I. \& Førland E.J. 1994. Homogenizing long Norwegian precipitation series. Journal of Climatology 7, 1001-1013.

Hanssen-Bauer I., Solås M.K. \& Steffensen E.L. 1990. The climate of Spitsbergen. DNMI Klima 39/90. Oslo: Norwegian Meteorological Institute.

Hartmann D.L., Klein Tank A.M.G., Rusticucci M., Alexander L.V., Bronnimann S., Charabi Y., Dentener F.J., Dlugokencky E.J., Easterling D.R., Kaplan A., Soden B.J., Thorne P.W., Wild M. \& Zhai P.M. 2013. Observations: atmosphere and surface. In T.F. Stocker et al. (eds.): Climate change 2013. The physical science basis. Contribution of Working Group I to the fifth assessment report of the Intergovernmental Panel on Climate Change. Pp. 159-254. Cambridge: Cambridge University Press.

Hegseth E.N. \& Tverberg V. 2013. Effect of Atlantic water inflow on timing of the phytoplankton spring bloom in a High Arctic fjord (Kongsfjorden, Svalbard). Journal of Marine Systems 113-114, 94-105.

Hesselberg T. \& Johannessen T.W. 1958. The recent variations of the climate at the Norwegian Arctic stations. In R.C. 
Sutcliffe (ed.): Polar Atmosphere Symposium. Part I. Meteorology section. Pp. 18-29. London: Pergamon Press.

Hisdal V. 1976. Geography of Svalbard. A short survey. Oslo: Norwegian Polar Institute.

Hughes N.E. \& Wagner P.M. 2015. Knowledge and forecasts of sea ice extent and icebergs- "Barents Sea SE" and "Jan Mayen." MET Report 26/15. Oslo: Norwegian Meteorological Institute.

Ivanov B.V., Sviashchennikov P.N., Zhuravskiy D.M., Pavlov A.K. \& Førland E.J. 2014. Metadata for a long-term climate series from the Russian meteorological station "Pyramiden" (1948-1957) at Svalbard. Czech Polar Reports 4, 57-62.

Kalnay E., Kanamitsu M., Kistler R., Collins W., Deaven D., Gandin L., Iredell M., Saha S., White G., Woollen J., Zhu Y., Leetmaa A., Reynolds R., Chelliah M., Ebisuzaki W., Higgins W., Janowiak J., Mo K.C., Ropelewski C., Wang J., Jenne R. \& Joseph D. 1996. The NCEP/NCAR 40-year reanalysis project. Bulletin of American Meteorological Society 77, 437-471.

Köppen W. 1888. Über die ableitung wahrer Tagesmittel aus den Beobachtungen um 8 h a.m., 2 h p.m. und 8 h p.m. (On the calculation of true monthly means from the observations at 8 h a.m., 2 h p.m. and 8 h p.m.) Annalen der Hydrographie und Maritimen Meteorologie 16, 341-354.

Muckenhuber S., Nilsen F., Korosov A. \& Sandven S. 2016. Sea ice cover in Isfjorden and Hornsund, Svalbard (20002014) from remote sensing data. The Cryosphere 10, 149-158.

Nilsen F., Cottier F., Skogseth R. \& Mattsson S. 2008. Fjordshelf exchanges controlled by ice and brine production: the interannual variation of Atlantic Water in Isfjorden, Svalbard. Continental Shelf Research 28, 1838-1853.

Nordli Ø. 2010. The Svalbard Airport temperature series. Bulletin of Geography Physical Geography Series 3, 5-25.

Nordli Ø., Alexandersson H., Frich P., Førland E.J., Heino R., Jónsson T., Tuomenvirta H. \& Tveito O.E. 1997. The effect of radiation screens on Nordic time series of mean temperature. International Journal of Climatology 17, 1667-1681.

Nordli Ø., Hanssen-Bauer I. \& Førland E.J. 1996. Homogeneity analyses of temperature and precipitation series from Svalbard and Jan Mayen. DNMI Klima 16/96. Oslo: Norwegian Meteorological Institute.

Nordli Ø., Przybylak R., Ogilvi A.E.J. \& Isaksen K. 2014. Longterm temperature trends and variability on Spitsbergen: the extended Svalbard Airport temperature series, 1898-2012. Polar Research 33, article no. 21349, doi: http://dx.doi.org/ 10.3402/polar.v33.21349

Nordli Ø. \& Tveito O.E. 2008. Calculation of monthly mean temperature by Köppen's formula in the Norwegian station network. Met.no Report 18/2008. Oslo: Norwegian Meteorological Institute.

Pavlov A.K., Tverberg V., Ivanov B.V., Nilsen F., Falk-Petersen S. \& Granskog M.A. 2013. Warming of Atlantic water in two west Spitsbergen fjords over the last century (1912-2009). Polar Research 32, article no. 11206, doi: http://dx.doi.org/ 10.3402/polar.v32i0.11206
Pithan P. \& Mauritsen T. 2014. Arctic amplification dominated by temperature feedbacks in contemporary climate models. Nature Geoscience 7, 181-184.

Przybylak R. 2007. Recent air-temperature changes in the Arctic. Annals of Glaciology 46, 316-324.

Przybylak R., Araźny A., Nordli Ø., Finkelnburg R., Kejna M., Budzik T., Migala K., Sikora S., Puczko D., Rymer K. \& Rachlewicz G. 2014. Spatial distribution of air temperature on Svalbard during 1 year with campaign measurements. International Journal of Climatology 34, 3702-3719.

Przybylak R., Wyszyński P., Nordli Ø. \& Strzyżewski T. 2016. Air temperature changes in Svalbard and the surrounding seas from 1865 to 1920. International Journal of Climatology 36, 2899-2916.

Screen J.A., Deser C. \& Simmonds I. 2012. Local and remote controls on observed Arctic warming. Geophysical Research Letter 39, L10709, doi: http://dx.doi.org/10.1029/2012GL0 51598

Serreze M.C., Barret A.P. \& Cassano J.J. 2011. Circulation and surface controls on the lower tropospheric air temperature field in the Arctic. Journal of Geophysical ResearchAtmospheres 116, D07104, doi: http://dx.doi.org/10.1029/ 2010JD015127

Smolencev N.K. 2005. Osnovy teorii vejvletov. Vejvlety v Matlab. (Fundamentals of the theory of wavelets. Wavelets in Matlab.) Moscow: DMK Press.

Sneyers R. 1990. On statistical analysis of series of observation. WMO Technical Note 143, WMO no. 415. Geneva: Secretariat of the World Meteorological Organization.

Steffensen E. 1969. The climate and its recent variations at the Norwegian Arctic stations. Meteorologiske Annaler 5(8). Oslo: Norwegian Meteorological Institute.

Steffensen E. 1982. The climate at Norwegian Arctic stations. Klima 5. Oslo: Norwegian Meteorological Institute.

Steffensen E., Nordli Ø. \& Hanssen-Bauer I. 1996. Stasjonshistorie for norske meteorologiske målinger $i$ Arktis. (Station history for Norwegian measurements in the Arctic.) DNMI Klima 17/96. Oslo: Norwegian Meteorological Institute.

Svendsen H., Beszczynska-Møller A., Hagen J.O., Lefauconnier B., Tverberg V., Gerland S., Ørbæk J.B., Bischof K., Papucci C., Zajaczkowski M., Azzolini R., Bruland O., Wiencke C., Winther J.-G. \& Dallmann W. 2002. The physical environment of Kongsfjorden-Krossfjorden, an Arctic fjord system in Svalbard. Polar Research 21, 133-166.

Wilks D.S. 1995. Statistical methods in the atmospheric science. An introduction. Amsterdam: Academic Press.

Winther J.-G., Bruland O., Sand K., Gerland S., Marechal D., Ivanov B., Glowacki P. \& König M. 2003. Snow research in Svalbard. Polar Research 22, 125-144.

WMO 1996. Climatological normals (CLINO) for the period 19611990. WMO/OMM 847. Geneva: World Meteorological Organization.

Zhuravskiy D., Ivanov B. \& Pavlov A. 2012. Ice conditions at Gronfjorden Bay, Svalbard, from 1974 to 2008. Polar Geography 35, 169-176. 